\title{
The Key Factors Influencing Internet Finances Services Satisfaction: An Empirical Study in Taiwan
}

\author{
Ming-Chih Chen ${ }^{1}$, Shih-Shiunn Chen ${ }^{1}$, Hung-Ming Yeh${ }^{2}$, Wei-Guang Tsaur ${ }^{3}$ \\ ${ }^{1}$ Graduate Institute of Business Administration, Fu-Jen Catholic University, Taiwan \\ ${ }^{2}$ Department of Accounting, Fu-Jen Catholic University, Taiwan \\ ${ }^{3}$ Department of Economics, Fu-Jen Catholic University, Taiwan \\ Email: 081438@mail.fju.edu.tw, "sschen@tabf.org.tw, 012939@mail.fju.edu.tw, tsaur66@hotmail.com
}

Received 30 May 2016; accepted 19 June 2016; published 22 June 2016

Copyright (C) 2016 by authors and Scientific Research Publishing Inc.

This work is licensed under the Creative Commons Attribution International License (CC BY).

http://creativecommons.org/licenses/by/4.0/

c) (†) Open Access

\section{Abstract}

The global innovation of information technology fundamentally reshaped the finance technology and the flourishing development over the past decade. The high coverage of both the internet network and the mobile phone has facilitated Taiwan to become one of the most potential internet finance regions. This study aims to empirically validate the technology acceptance model (TAM 3) for exploring the key factors that influence the internet finance development. SEM was adopted to investigate both the hypothesis and the path coefficient associations among the constructs and their significance. Confirmed factor analysis for the instrument validity and reliability assessment was made. Hierarchy regression was performed to test the moderator effect of experience and voluntariness. This study result found that Taiwan finance customers had high expectations of information security and preferred high technology products with complex functions. The result demonstrated that customer's Use Behavior was influenced by Perceived of Usefulness, not Perceived of Ease of Use. The moderator effect result in Experience had a positive moderator effect on Objective Usability to Perceived Ease of Use. This research extracted the key factors that influenced the internet finance development in Taiwan for providing both local government and internet finance developing countries guidelines while concurrently developing an internet finance development strategy.

\section{Keywords}

Internet Finance, TAM, SEM, Taiwan

\footnotetext{
${ }^{*}$ Corresponding author.
}

How to cite this paper: Chen, M.-C., Chen, S.-S., Yeh, H.-M. and Tsaur, W.-G. (2016) The Key Factors Influencing Internet Finances Services Satisfaction: An Empirical Study in Taiwan. American Journal of Industrial and Business Management, 6, 748-762. http://dx.doi.org/10.4236/ajibm.2016.66069 


\section{Introduction}

E-commerce with its characteristics of convenience, low cost, fast transaction has fundamentally reshaped the internet finance industry and flourishing development over the past decade. In recent years, the internet network has replaced newspapers and television. The social media of Facebook and Line have had an explosive growth. Mobile Apps have created a new living style of "mobile phone overuse". The digital age has tremendously impacted on people's daily lives. For the banking industry, a bank customer no longer has to visit their bank. The internet finance development has had a great impact on both banking marketability and structural transforming. Brett King, in his 2012 publication of BANK 3.0, "Why Banking Is No Longer Somewhere You Go but Something You Do", mentioned that the bank customer behavior had changed into four stages. These stages are the social media stage, the mobile devices stage, the mobile payment stage, and the final stage; banking is no longer considered as a place to go, but something you do. The marketability of social media from Facebook and LINE can't be ignored. Mobile devices have become the people's daily necessities. Mobile payment changed the e-commerce transaction behavior, and the bank industry needed structural transforming to adopt to the digital age's customer need.

In fact, global internet financial development since 2008 has consisted of a heavy investment flow into the FinTech (Technology and Finance). Investment grew from 1 billion US dollars in 2008 to 40 billion US dollars in 2013. In the year of 2014, there was a high increase to 12.2 billion US dollars, of which the United States accounted for nearly $80 \%$, Europe counted for $12 \%$ in second, and the whole of the Asia only accounted for $6 \%$ [1]. London and New York cities are obviously the global leader cities in FinTech. These two cities accounted for $90 \%$ of the investment and income of the global FinTech share. FinTechin China's third party payment platform of YU E BAO, WeBank, and Mi-Pay grew rapidly in the past decade. The high coverage of the internet network and mobile phone facilitated China to become one of the most potential internet finance countries.

Global internet financial development is not entirely limited to the developed countries. In developing countries or undeveloped countries where finance is not well established, these countries have a higher dependence on a successful internet finance platform. For example, Africa has no physical banking entity in most regions, and develops higher degree of internet finance environment, particularly when mobile banking has been created through the high network penetration coverage. The Republic of Kenya, the country with world's highest coverage of mobile payment, about $89 \%$ of the population is familiar with mobile payment, and around $70 \%$ of the population uses mobile money.

Taiwan internet financial development has been slower than in other regions, but the banking industry is impacted by the new trend of Bank 3.0, Finance Technology (FinTech) and Taiwan's regulation. The Financial Supervisory Commission (Taiwan) proposed "The creation of a digitized financial environment 3.0" in 2015 and also unveiled a grand office of financial technology in September 2015 for promoting the transform action plan of financial institutions. However, the key factors that influence the present internet finance development need to be discovered. Government, finance industry, and academic still need to fulfill science gap for exploring those factors which lead to our study motivation.

From the literature review, this study finds that it seems that the global internet finance development is not necessarily related to the maturity of local financial development, but related to the key factors of being accustomed to using a credit card, convenient ATM location, numerous convenience stores, regulation in of e-commerce business etc. Yet, it is unclear whether these key factors influence FinTech development. This study aims to empirically validate a technology acceptance model for exploring the key factors that influence the internet finance development. This study examines the relation between a customer's satisfactions in Technology Acceptance Model (TAM). The main purposes of this study include:

1. An empirical validation of the technology acceptance model to extract the key factors that influence the internet finance development in Taiwan.

2. Providing local government and Internet finance developing countries guidelines to utilize when making Internet finance development policy and strategy.

\section{Literature Review}

\subsection{The Factors Influencing Internet Finance Development}

In today's highly competitive market of rapidly changing businesses environment, all business are using creativ- 
ity and innovation to provide excellent services for customers to create business opportunities. The internet can be regarded as the nervous system of the 21st century. Through the WWW system, messages between human and systems can be integrated, and thus produce different benefits. Contemporary organizations begin to use neural network advantages of the internet both to provide service and create value. The bank industry will not be absent. The banking industry has been using the information technology to provide electronic financial services to improve the industry's internal quality, and to provide their customers' account service. In the internet age, the bank utilized internet characteristics to both increased customer volume, and to reduce transaction costs and worldwide sales [2]-[4]. Generally speaking, the internet banking through internet, television, mobile telephone provides banking products, diversity services, and responds to customer demands [4]. Through the internet, the business hours of the bank can be extended to 24 hours a day. Customers can access bank services anytime and anywhere without waiting in the line [5].

For financial institutions, online banking not only provides $7 \times 24$ hours service advantages, but also establishes standardized services, thus reducing labor, service costs, and expanding special service options [6]. For most banks, online banking, e-banking and internet banking are the same. From the consumer's point of view, both internet banking and online banking allows the bank's customers to save time, money and resources. From the bank's point of view, the internet can reduced costs significantly, increase revenue and improve service quality. Academic studies have proved that use of the internet has resulted in win-win financial advantages both for the bank and for the customer [7].

In developed countries like the United States, Great Britain, Canada, Austria, and France, their internet banking systems are rapidly developing. However, for developing countries, their internet finance is still considered an innovative financial service. Acceptance for internet finance will be influenced by different countries and will depend on their different cultural background, social environment and ethnic differences [8]. For example, in Sudan, the level of retail bank customers that use online banking will influence electronic banking development. A study has proved individual with higher income, with a computer account, and with internet experience, would tend to use online banking services. But the same study also found, there was not enough evidence of any significant in gender, marital status, education level and occupation differences on utilizing online banking [9]. The result shows that cultural background, the environment and ethnic differences may be the factors that greatly influence the development of internet finance.

From another point of view, developing countries should profit from the financial experience of developed countries, to deploy online banking or internet banking application rapidly. With a chance to implement a "leapfrog” development, developing countries will gain more benefit from financial services of the internet business in comparison with developed countries [10].

When previous study observe on southern region of Saharan Africa, researcher see that commercial banks are attempting to introduce an online banking system to improve business operations, reduce costs, improve efficiency, and also provide consumers with more convenient services [10]. In a developing country like Nigeria, internet finance consists of business innovative models. The rapid development of internet technology has had a huge impact on people's daily lives, as well as on a banking business model. Local customer are concerned that key factors influencing internet finance development are information infrastructure, ease of use, technology usefulness and the platform security problem [11].

In a study concerned with Jordan, survey investigated the customers of a commercial bank who had e-banking services. The result was that customers were concerned with the factors of easy access, reliability, design, cost/ fees/charges, the electronic banking equipment, privacy/risk/and verification. Those factors are all associated with customer satisfaction. The result also demonstrated that technology created business innovation and transformed the business model, thus allowing local banks to provide innovation service through an internet finance platform [12].

From a TAM research of exploring perceptions of Malaysia customer internet finance and mobile banking services, empirical results show that convenience, design, perceived risk, perceived usefulness and perceived ease of use are the factors to be considered in the internet financial services development stage [13]. In addition to evaluate the customers' satisfaction with banking services, the research resulted in 5 relative factors, which are cost, convenience, security, online banking and customer service [14].

An investigation of which factors will affect the Thailand customer behavioral intentions when using online banking. Proved that quality management and trust are both very important attributes. Online banking not only provides banking services anytime and anywhere, but also reduces costs. The result found that system quality 
and service quality influence the degree of trust of a typical Thailand customer to begin to use online banking service, but there was a negative influence on the information quality variable [5] [15].

Information and communication technology (ICT) applications and services development change people's daily routine indeed. The bank of Greece used the internet finance to provide diversified service. Their study examination of an internet finance quality through a conceptual model had the 7 factors of efficiency, system, usefulness, satisfaction, privacy, enthusiasm, compensation [16]. In Canada a financial environment research, result showed the 3 key factors which caused to local customers accept internet banking were risk, security and trust [7].

In order to discuss the important factor of customer loyalty of online banking, and to measure customer loyalty from different public and private banks in India, researchers explored the relationship of service quality and the key factors of system usefulness, site aesthetics, ease of use, technical performance, reliability, privacy, trust, enthusiasm, and custom made. That result was that customer satisfaction improved customer loyalty [17]. In addition to assessing the key factors that impact a consumer use of internet finance, the Indian researchers established a research model with the factors of comparative advantage, perceived usefulness, perceived ease of use, trust, security, legal issues, behavior, subject norm and image [18].

A research found that 11 key factors influence the Sudan customer use of internet banking which include breakdown frequency of an ATM, an ATM and electronic point of sale (EPOS), inability of access the Internet, technical problems of report mechanism, an inconvenient location, blurred legislation of electronic transactions protection, and both prevention and handling of transaction processing errors problems [9].

The rapid growth of the internet finance development has fundamentally changed the interaction between banks and their customers, in order to better understand the relationship between the financial service quality, customer satisfaction and loyalty of a developing country. Researchers of South Africa investigated the key factors that influence the customer perception of internet banking service quality. The 7 key factors of online banking which affect customer perception of service quality are included: trust, response speed, ease of use, access accessibility, satisfaction, speed and accuracy, and contact [3].

As a result of the great leap forward of science and technology, internet finance is not the only means of financial services available on internet applications. Online banking, mobile banking, internet securities companies and internet insurance companies are all parts of the financial transactions platform of internet finance. Internet banking is the banking service that developed as a result of the internet finance. Customer receive different financial services through internet finance. Services include account balance inquiries, transfers, and payments. In addition, customers can enjoy $7 \times 24$ financial services through the internet finance network without coming to the bank.

In summary, the key factors that influence the internet financial development are not only the Convenience factor. This study summarized the relevant factors from the literature review, and concluded that the key factors that influence the internet finance development are Convenience, Usefulness, Trust, Cost, and User background.

\subsection{Technology Acceptance Model, TAM}

\subsubsection{TAM 1}

Technology acceptance model (TAM) is the most widely employed model of Technology adoption and usage [19]. It was introduced in Theory of Reasoned Action (TRA) of Belief, Attitude, Intention, and Behavior by Davis et al., 1989. TAM suggests two specific construct: Perceived Ease of Use (PEOU) and Perceived Usefulness (PU). Those construct will influence the customer's attitude toward use. Furthermore, TAM will influence on behavioral intention and result in actual system use. TAM model is shown in Figure 1.

As many scholars questioned about the framework of TAM, Davis made some changes to TAM in 1993. He made use of scholars' suggestions to improve the technology explanatory power of TAM. The new model used System Design to replace External Variables, and deleted Attitude Toward Using. As a result, Behavioral Intention to Use will influence the Actual system use directly [20].

\subsubsection{TAM 2}

For improve the explanatory power of the TAM model, Davis and Venkatesh (2000) proposed TAM 2 with more variables [21]. TAM2 is separated into 2 parts. The first is Social Influence Process, the other is Cognitive Instrumental Process. The social Influence Process includes both Subjective Norm and Image variables. The 


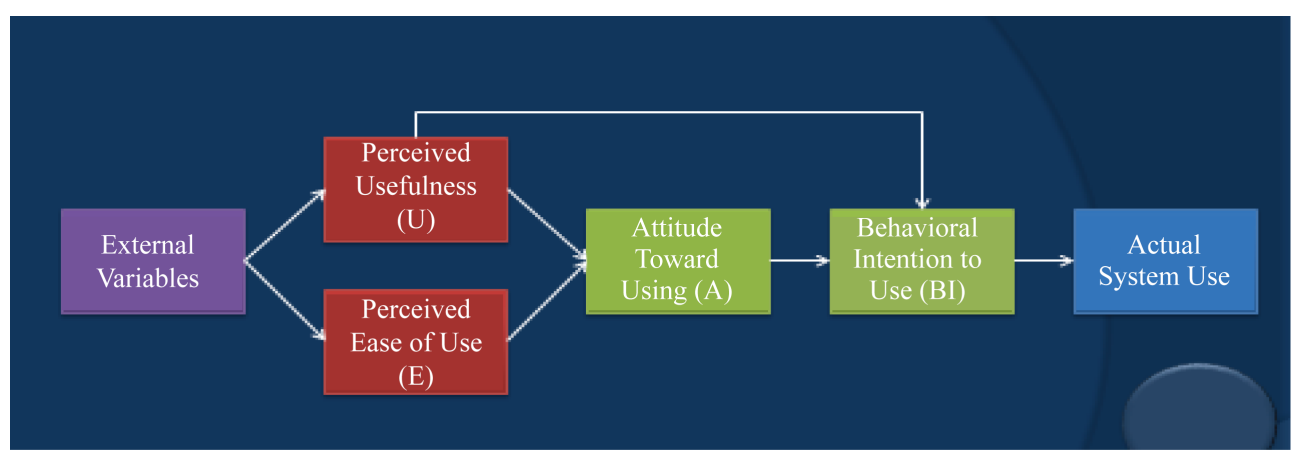

Figure 1. Technology acceptance model, Davis (1989).

moderator variable includes Experience and Voluntariness variables. The cognitive Instrumental Process include Output Quality, Job Relevance, Result Demonstrability influence Perceived Usefulness. The new model is big difference from TAM 1. TAM 2 is shown in Figure 2.

\subsubsection{TAM 3}

Venkatesh and Bala proposed TAM 3 in 2008 [22]. In order to improve the Perceived Ease of Use, this model includes the personal external variables of Computer Self-efficacy, Perceptions of External Control, Computer Anxiety, Computer Playfulness, Perceived Enjoyment and Objective Usability into the TAM3. TAM 3 is shown in Figure 3.

\section{Methodology}

\subsection{Research Model \& Hypotheses}

This study aims to extract the key factors that influence customer satisfaction in the Technology Acceptance Model (TAM), and to explore the relation between the internet finance developed in Taiwan. For improve the explanatory power when compared with TAM1 \& TAM2, Venkatesh (2000) TAM 3 of the determinants of Perceived Ease of Use by building on the anchoring and adjustment framing of human decision making was adopted as the research model (shown in Figure 4). Anchoring included variables of Computer self-efficiency, Perceptions of External Control, Computer Anxiety, and Computer Playfulness. Adjustment included variables of Perceived Enjoyment and Objective Usability.

The 16 hypotheses are addressed to test whether the relationship between Subjective Norm, Image, Job Relevance, Output Quality, Result Demonstrability, Computer self-efficiency, Perceptions of External Control, Computer Anxiety, Computer Playfulness, Perceived Enjoyment, Objective Usability, Perceived Ease of Use, Perceived Usefulness, Behavioral Intention, and the result in Use Behavior. Hypotheses H2, H2a-g, H3 are the moderator effect of both Experience and Voluntariness. The hypotheses table is shown in Table 1.

To measure instrument development, a self-administered questionnaire was developed based on the operational definitions of the constructs. All constructs were measured using a five-point Likert-type scale for each item, anchored between "strongly agree" (coded as 1) and "strongly disagree" (coded as 5), with the midpoint of "neither agree nor disagree" (coded as 3). Because the subjects of this study were confined to the native Taiwanese population, the questionnaire hence was written in traditional Chinese characters.

\subsection{Research Method}

Model measurement assessment, statistical analysis began with the descriptive statistics in the IBM Spss statistic 21 for the demography information which contributes to realize the characteristics of the data collected. A Sixstage analytical procedure was performed on the data to ensuring that the findings were derived from a wellconstructed instrument possessing sound psychometric properties. Stage one demography information analysis realized the characteristics of the data collected. Stage two involved the assessment of reliability analysis for the questionnaire reliability measurement. Stage three, confirmed factor analysis was performed for validity measurement. In stage four, SEM analysis the goodness of fit measurement, the model must be taken into consideration before the structural model was tested. In stage five, the structural model was analyzed to investigate the 


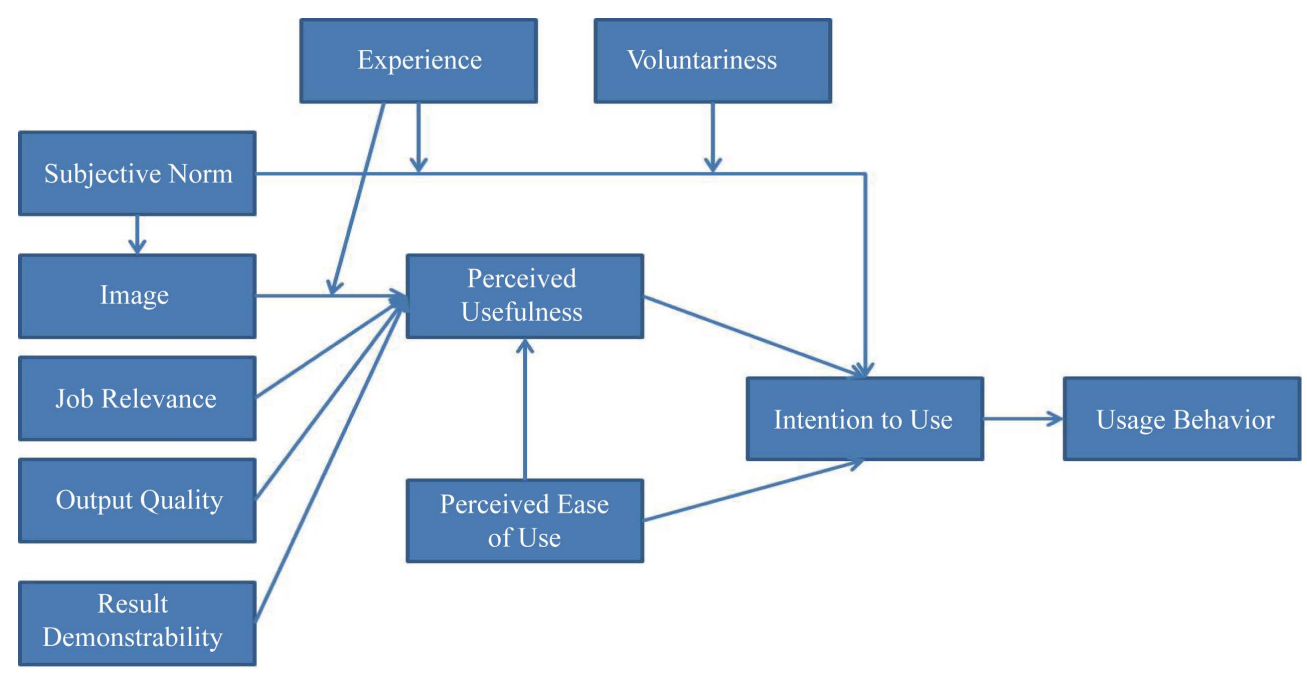

Figure 2. TAM 2, Venkatesh (2000).

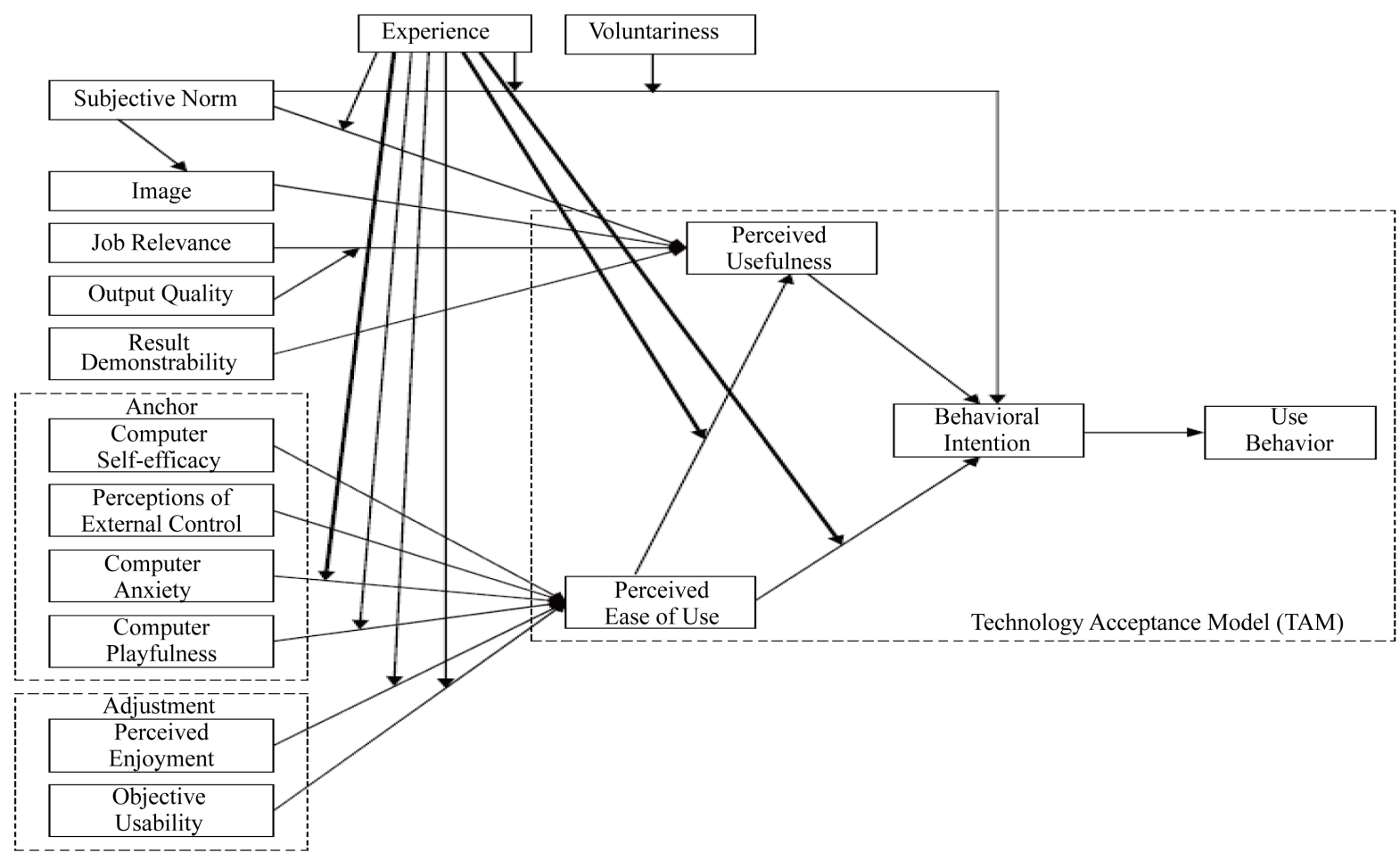

Figure 3. TAM 3, Venkatesh (2008).

hypothesis associations among the constructs and their significance. Hierarchy regression was performed to test the moderator effect both of Experience and of Voluntariness. For stage six, path coefficient was analyzed by SEM technique using Amos software with a maximum likelihood estimation (MLE) approach.

\subsection{Sampling}

Structural equation modeling analysis required a relatively large sample to maintain both statistical test power and the stability of the parameter estimates. The number of samples depends on the number of attributes and the latent variables within the model. According to Schumacker and Lomax (2010), over 300 samples could archive SEM performance. This study aims to understand the key factors that influence Taiwanese consumers to accept 


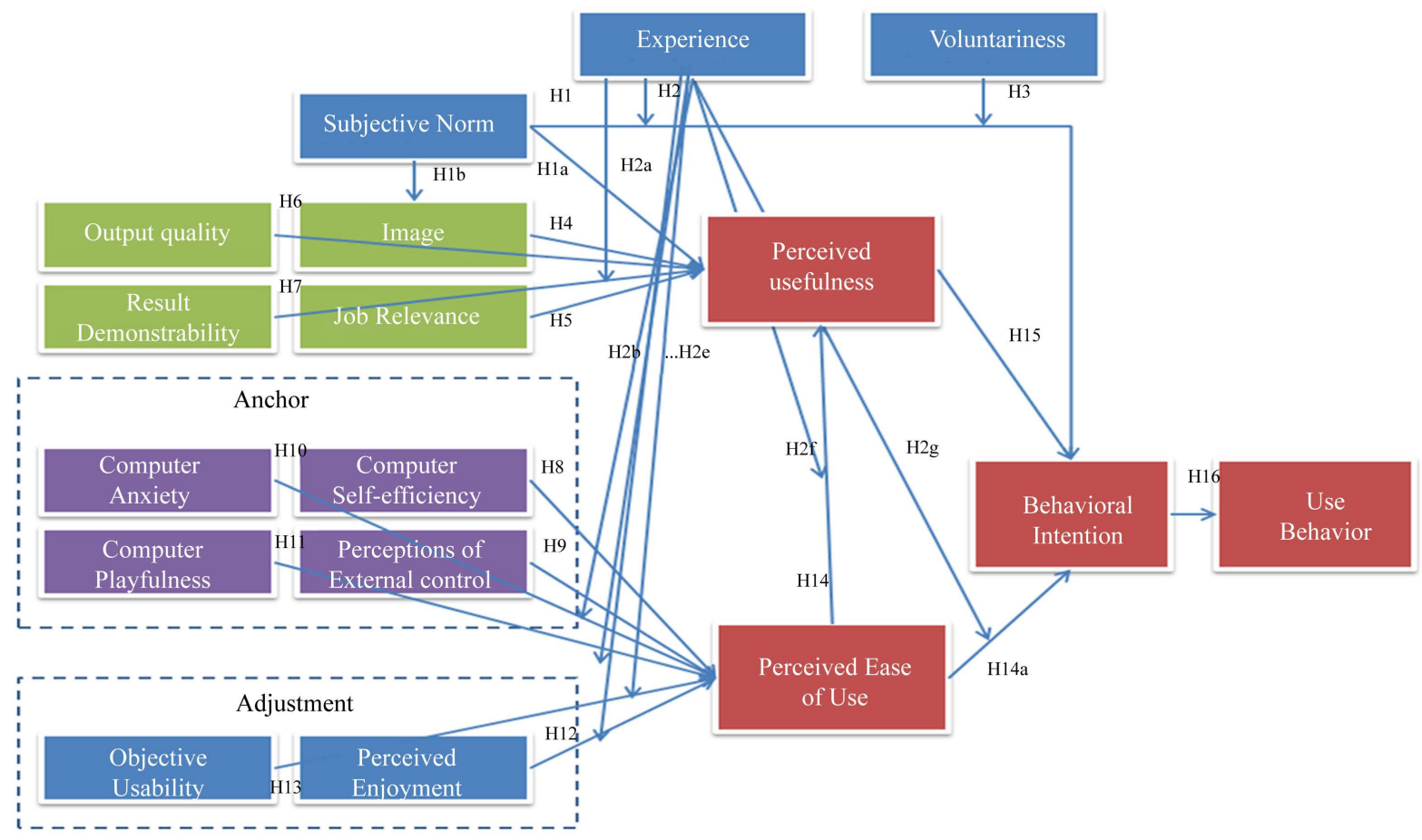

Figure 4. Internet finance technology acceptance model.

\section{Table 1. Hypotheses.}

H1: Subjective Norm has a positive influence on Behavioral Intention of internet finance Service.

H1a: Subjective Norm has a positive influence on Perceived Usefulness of internet finance Service.

H1b: Subjective Norm has a significant difference on the image of internet finance Service.

H2: Experience has a positive moderator effect on Subjective Norm to Behavioral Intention of internet finance Service.

H2a: Experience has a positive moderator effect on Image to Perceived Usefulness of internet finance Service.

H2b: Experience has a positive moderator effect on Computer Anxiety to Perceived Ease of Use.

H2c: Experience has a positive moderator effect on Computer Playfulness to Perceived Ease of Use
H2d: Experience has a positive moderator effect on Perceived Enjoyment to Perceived Ease of Use.

H2e: Experience has a positive moderator effect on Objective Usability to Perceived Ease of Use.

H2f: Experience has a positive moderator effect on Perceived Ease of

Use to Perceived Usefulness of internet finance Service.

H2g: Experience has a positive moderator effect on Perceived Ease of Use to Behavioral Intention of internet finance Service.

H3: Voluntariness has a positive moderator effect on Subjective Norm

to Behavioral Intention of internet finance Service.

H4: Image has a positive influence on Perceived Usefulness of internet finance Service.

H5: Job Relevance has a positive influence on Perceived Usefulness of internet finance Service.
H6: Output Quality has a H13: Objective Usability has a positive influence on Perceived positive influence on Perceived Usefulness of internet finance Ease of Use of internet finance Service. Service.

H7: Result Demonstrability has H14: Perceived Ease of Use has a positive influence on a significant difference on Perceived Usefulness of internet Perceived Usefulness of finance Service. Internet finance Service.

H8: Computer self-efficiency H14-a: Perceived Ease of Use has a positive influence on Perceived Ease of Use of internet finance Service. has a positive influence on Behavioral Intention of internet finance Service.

H9: Perceptions of External H15: Perceived Usefulness has Control has a positive influence on Perceived Ease of Use of internet finance Service. a positive influence on Behavioral Intention of internet finance Service.

H10: Computer Anxiety has a H16: Behavioral Intention has a egative influence on Perceived positive influence on Use Ease of Use of internet finance Behavior of internet finance Service. Service.

H11: Computer Playfulness has a positive influence on Perceived Ease of Use of internet finance Service.

H12: Perceived Enjoyment has a positive influence on Perceived Ease of Use of internet finance Service.

H2, H2a-g, H3 are moderator effect. 
internet banking. The native Taiwanese population of finance consumers is the target samples used to meet this research objective. A Google survey from April $13^{\text {th }}$ to $30^{\text {th }} 2016$ was adopted, and the final survey obtained 307 valid samples.

\section{Empirical Result \& Analysis}

\subsection{Demographic Information (Table 2)}

Items assessing demographic characteristics were included in the questionnaire. Participants were asked to report their gender, age, education, and awareness toward their internet finance experience. According to the descriptive statistics result of the demographic information from the samples, $84.7 \%$ of the participants had a higher education level "university". $72.3 \%$ of the participants had experience dealing with personal finance through the web, mobile devices, and technology equipment or the internet financial platform. 85.3\% of the participants had experience shopping online or shopping on the internet or television. The most commonly used forms of payment were $46.9 \%$ by cash and $49.2 \%$ by credit card. Participants in the surrounding area have a bank or an ATM or a convenience store or a post office nearby (Multiple choice), the result showed $73.6 \%$ had bank, ATM, convenience store and post office in the surrounding area. The result demonstrated that participants were surrounded by a good financial environment. $54.4 \%$ of the participants agreed and very much agreed on the question of "I love to use new technology products; therefore, I like to use the internet finance service platform".

\subsection{Reliability Analysis}

The Cronbach's alpha coefficient is commonly used to measure reliability of the questionnaires. Hair et al. (1998) stated that alpha and construct-reliability values greater than or equal to 0.70 and a variance-extracted measure greater than 0.50 indicates sufficient scale and factor reliability.

Cronbach's scores were calculated to assess the internal consistency reliability of the questionnaire. All the results are presented in Table 3. As seen, all the scales had high levels of performance 0.971. Latent variables of Image, Job Relevance, Output Quality, Perceived Ease of Use, and Behavioral Intention, had Cronbach's scores over 0.9. The latent variables of Subjective Norm, Experience, Computer Self-efficiency, Computer Anxiety, Computer Playfulness, Perceived Enjoyment, Objective Usability, Perceived Usefulness, and Use Behavior, had Cronbach's scores over 0.8. The result shows that questionnaire is reliable in terms of their internal consistency.

\subsection{Validity Analysis}

Confirmatory Factor Analysis (CFA) of Structural Equation Modeling (SEM) has been used to test the validity and reliability of the instruments. Various tests of Standardized Regression Weights of factor loading, Square Multiple Correlation, Average Variance Extracted and Composite Reliability have depicted improved result with better validity and reliability. The construct validity is determined by the average value AVE (Average Variance Extracted). The Composite Reliability (CR) is intended to determine the consistency of construct validity indicators. Fornell and Larcker (1981) suggested a CR greater than 0.6 and an AVE greater than 0.5. The result demonstrated that all factor loading are greater than 0.5 and the SMC greater than 0.2, both CR and AVE are greater than 0.7 and 0.5 , which show a satisfaction of validity and reliability within the instrument (Table 4).

\section{4, Goodness of Fit Test}

Table 5 shows the results of the structural model of this research. The overall goodness of fit measurement of the SEM, RMSEA $=0.081, \mathrm{NFI}=0.824, \mathrm{IFI}=0.875, \mathrm{CFI}=0.874$, indicates that the fit test of the model is very satisfactory.

\subsection{Hypotheses Test and Moderator Test}

Structural equation modeling (SEM) is used to verify the relationship between variables, and a path coefficient comparison analysis was adapted for model verification and hypothesis testing. The paths analysis of $\mathrm{H} 1$, H1a, H4, H9, H11 and H14a are not supported; however, the remaining 11 hypotheses are significant and are 
Table 2. Demographic information.

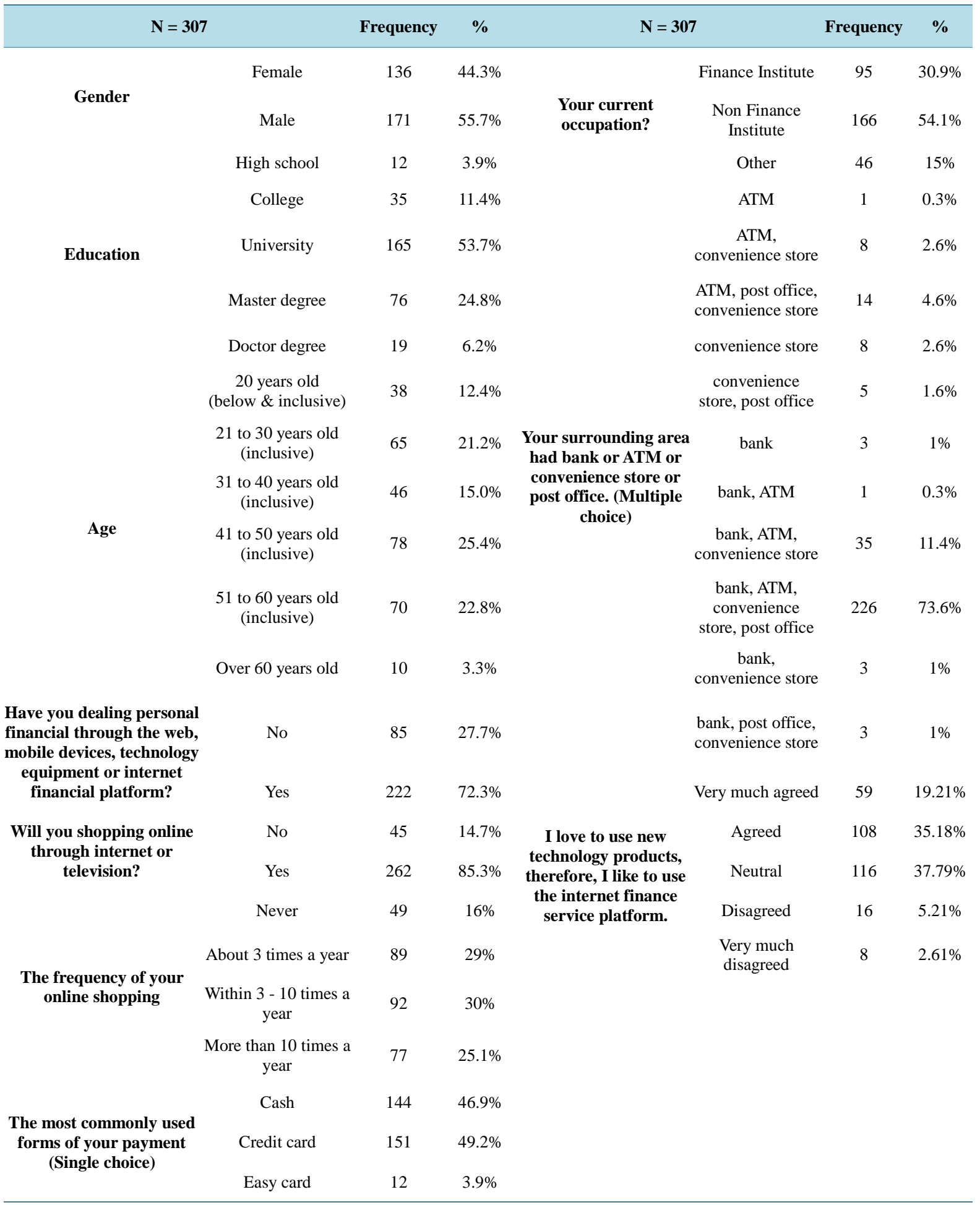

supported in this study. Hierarchy regression analysis was performed for the H2, H2a-g, and H3 moderator tests. From the result, this study found out that the 8 hypotheses of Experience attribute's moderate effect are not significant, but the H2e of Experience has a positive moderator effect on Objective Usability to Perceived Ease of Use is supported with the moderator effect. The results are shown in Table 6. 
Table 3. Reliability test.

\begin{tabular}{lc}
\hline Cronbach's alpha & $\mathbf{N}=\mathbf{3 0 7}$ \\
\hline 19 Latent Variables & 0.971 \\
Subjective Norm & 0.894 \\
Experience & 0.866 \\
Voluntariness & 0.713 \\
Image & 0.946 \\
Job Relevance & 0.919 \\
Output Quality & 0.900 \\
Result Demonstrability & 0.778 \\
Computer self-efficiency & 0.851 \\
Perceptions of External Control & 0.792 \\
Computer Anxiety & 0.887 \\
Computer Playfulness & 0.853 \\
Perceived Enjoyment & 0.814 \\
Objective Usability & 0.871 \\
Perceived Ease of Use & 0.927 \\
Perceived Usefulness & 0.889 \\
Behavioral Intention & 0.912 \\
Use Behavior & 0.872 \\
\hline
\end{tabular}

Cronbach’s $\alpha<=0.7$ acceptable, 0.8 - 0.9 good, 1.0 excellent.

Table 4. Validity test.

\begin{tabular}{|c|c|c|c|c|c|c|c|c|c|c|c|}
\hline $\begin{array}{c}\text { Latent } \\
\text { variables }\end{array}$ & Question & $\begin{array}{l}\text { Factor } \\
\text { loading }\end{array}$ & SMC & CR & AVE & $\begin{array}{c}\text { Latent } \\
\text { variables }\end{array}$ & Question & $\begin{array}{l}\text { Factor } \\
\text { loading }\end{array}$ & SMC & $\mathbf{C R}$ & AVE \\
\hline \multirow{3}{*}{ Subjective Norm } & A1 & 0.719 & 0.517 & \multirow{3}{*}{0.888} & \multirow{3}{*}{0.667} & \multirow{3}{*}{$\begin{array}{l}\text { Computer } \\
\text { Anxiety }\end{array}$} & L1 & 0.810 & 0.656 & \multirow{3}{*}{0.890} & \multirow{3}{*}{0.730} \\
\hline & & & & & & & L2 & 0.936 & 0.876 & & \\
\hline & A2 & 0.713 & 0.508 & & & & L3 & 0.811 & 0.658 & & \\
\hline \multirow{2}{*}{ Image } & E1 & 0.910 & 0.828 & \multirow{2}{*}{0.946} & \multirow{2}{*}{0.855} & \multirow{2}{*}{$\begin{array}{l}\text { Computer } \\
\text { Playfulness }\end{array}$} & M1 & 0.892 & 0.796 & \multirow[t]{2}{*}{0.855} & \multirow[t]{2}{*}{0.747} \\
\hline & E2 & 0.940 & 0.884 & & & & M2 & 0.835 & 0.697 & & \\
\hline \multirow{4}{*}{ Job Relevance } & $\mathrm{F} 1$ & 0.876 & 0.767 & \multirow{3}{*}{0.921} & \multirow{3}{*}{0.794} & \multirow{2}{*}{$\begin{array}{l}\text { Perceived } \\
\text { Enjoyment }\end{array}$} & $\mathrm{N} 1$ & 0.800 & 0.640 & \multirow[t]{2}{*}{0.817} & \multirow[t]{2}{*}{0.691} \\
\hline & F2 & 0.898 & 0.806 & & & & N2 & 0.861 & 0.741 & & \\
\hline & F3 & 0.900 & 0.810 & & & \multirow{3}{*}{$\begin{array}{l}\text { Objective } \\
\text { Usability }\end{array}$} & $\mathrm{O} 1$ & 0.925 & 0.856 & \multirow[t]{2}{*}{0.875} & \multirow[t]{2}{*}{0.778} \\
\hline & $\mathrm{H} 1$ & 0.805 & 0.648 & \multirow{6}{*}{0.902} & \multirow{6}{*}{0.647} & & $\mathrm{O} 2$ & 0.836 & 0.699 & & \\
\hline \multirow{5}{*}{ Output Quality } & $\mathrm{H} 2$ & 0.801 & 0.642 & & & & $\mathrm{P} 1$ & 0.850 & 0.723 & 0.931 & 0.773 \\
\hline & H3 & 0.840 & 0.706 & & & \multirow{4}{*}{$\begin{array}{l}\text { Perceived } \\
\text { Ease of Use }\end{array}$} & $\mathrm{P} 2$ & 0.827 & 0.684 & \multirow{5}{*}{0.895} & \multirow{5}{*}{0.740} \\
\hline & $\mathrm{H} 4$ & 0.766 & 0.587 & & & & P3 & 0.921 & 0.848 & & \\
\hline & \multirow{2}{*}{ H5 } & \multirow{2}{*}{0.809} & \multirow{2}{*}{0.654} & & & & $\mathrm{P} 4$ & 0.915 & 0.837 & & \\
\hline & & & & & & & Q1 & 0.834 & 0.696 & & \\
\hline \multirow{4}{*}{$\begin{array}{c}\text { Result } \\
\text { Demonstrability }\end{array}$} & $\mathrm{I} 1$ & 0.839 & 0.704 & & & & Q2 & 0.873 & 0.762 & & \\
\hline & $\mathrm{I} 2$ & 0.781 & 0.610 & 0.796 & 0.569 & Perceived & & & & & \\
\hline & I3 & 0.627 & 0.393 & & & Usefulness & & & & & \\
\hline & $\mathrm{J} 1$ & 0.791 & 0.626 & & & & Q3 & 0.873 & 0.762 & & \\
\hline $\begin{array}{c}\text { Computer } \\
\text { self-efficiency }\end{array}$ & $\mathrm{J} 2$ & 0.754 & 0.659 & 0.858 & 0.669 & & & & & & \\
\hline & J3 & 0.901 & 0.812 & & & Behavioral & $\mathrm{R} 1$ & 0.904 & 0.817 & 0.912 & 0.838 \\
\hline & $\mathrm{K} 1$ & 0.805 & 0.648 & & & Intention & $\mathrm{R} 2$ & 0.927 & 0.859 & & \\
\hline $\begin{array}{l}\text { Perceptions of } \\
\text { External Control }\end{array}$ & $\mathrm{K} 2$ & 0820 & 0.672 & 0.795 & 0.660 & Use Rehavi & $\mathrm{S} 1$ & 0.882 & 0.778 & 0.872 & 0.774 \\
\hline & $\mathrm{N2}$ & 0.020 & 0.072 & & & Use Deflaviui & $\mathrm{S} 2$ & 0.877 & 0.769 & & \\
\hline
\end{tabular}


Table 5. SEM goodness of fit test.

\begin{tabular}{ccc}
\hline Goodness of fit statistics & Acceptable value & $\mathbf{N}=\mathbf{3 0 7}$ \\
\hline NFI-normed fit index & $0-1$ & 0.824 \\
IFI-incremental fit index & $0-1$ & 0.875 \\
CFI-comparative fit index & $0-1$ & 0.874 \\
RMSEA-root mean square error of approximation & $<0.1$ & 0.081 \\
\hline
\end{tabular}

Table 6. Hypotheses test and moderator test.

\begin{tabular}{|c|c|c|c|c|c|}
\hline Hypotheses & & $N=307$ & Hypotheses & & $\mathrm{N}=307$ \\
\hline $\begin{array}{l}\text { H1: Subjective Norm has a positive influence } \\
\text { on Behavioral Intention of internet finance } \\
\text { Service. }\end{array}$ & 0.446 & Not supported & $\begin{array}{l}\text { H5: Job Relevance has a positive } \\
\text { influence on Perceived Usefulness of } \\
\text { internet finance Service. }\end{array}$ & $* * *$ & Supported \\
\hline $\begin{array}{l}\text { H1a: Subjective Norm has a positive } \\
\text { influence on Perceived Usefulness of internet } \\
\text { finance Service. }\end{array}$ & 0.482 & Not supported & $\begin{array}{l}\text { H6: Output Quality has a positive } \\
\text { influence on Perceived Usefulness of } \\
\text { internet finance Service. }\end{array}$ & $* * *$ & Supported \\
\hline $\begin{array}{c}\text { H1b: Subjective Norm has a significant } \\
\text { difference on the image of internet finance } \\
\text { Service. }\end{array}$ & $* * *$ & Support & $\begin{array}{c}\text { H7: Result Demonstrability has a } \\
\text { positive influence on Perceived } \\
\text { Usefulness of internet finance } \\
\text { Service. }\end{array}$ & $* * *$ & Supported \\
\hline $\begin{array}{l}\text { H2: Experience has a positive moderator } \\
\text { effect on Subjective Norm to Behavioral } \\
\text { Intention of internet finance Service. }\end{array}$ & 0.781 & $\begin{array}{l}\text { Without } \\
\text { moderator } \\
\text { effect }\end{array}$ & $\begin{array}{l}\text { H8: Computer self-efficiency has a } \\
\text { positive influence on Perceived Ease } \\
\text { of Use of internet finance Service. }\end{array}$ & 0.016 & Supported \\
\hline $\begin{array}{l}\text { H2a: Experience has a positive moderator } \\
\text { effect on Image to Perceived Usefulness of } \\
\text { internet finance Service. }\end{array}$ & 0.581 & $\begin{array}{l}\text { Without } \\
\text { moderator } \\
\text { effect }\end{array}$ & $\begin{array}{c}\text { H9: Perceptions of External Control } \\
\text { has a positive influence on Perceived } \\
\text { Ease of Use of internet finance } \\
\text { Service. }\end{array}$ & 0.136 & Not supported \\
\hline $\begin{array}{c}\text { H2b: Experience has a positive moderator } \\
\text { effect on Computer Anxiety to Perceived } \\
\text { Ease of Use. }\end{array}$ & 0.263 & $\begin{array}{l}\text { Without } \\
\text { moderator } \\
\text { effect }\end{array}$ & $\begin{array}{c}\text { H10: Computer Anxiety has a } \\
\text { negative influence on Perceived Ease } \\
\text { of Use of internet finance Service. }\end{array}$ & $* * *$ & Supported \\
\hline $\begin{array}{c}\text { H2c: Experience has a positive moderator } \\
\text { effect on Computer Playfulness to Perceived } \\
\text { Ease of Use. }\end{array}$ & 0.279 & $\begin{array}{l}\text { Without } \\
\text { moderator } \\
\text { effect }\end{array}$ & $\begin{array}{l}\text { H11: Computer Playfulness has a } \\
\text { positive influence on Perceived Ease } \\
\text { of Use of internet finance Service. }\end{array}$ & 0.180 & Not supported \\
\hline $\begin{array}{c}\text { H2d: Experience has a positive moderator } \\
\text { effect on Perceived Enjoyment to Perceived } \\
\text { Ease of Use. }\end{array}$ & 0.469 & $\begin{array}{l}\text { Without } \\
\text { moderator } \\
\text { effect }\end{array}$ & $\begin{array}{l}\text { H12: Perceived Enjoyment has a } \\
\text { positive influence on Perceived Ease } \\
\text { of Use of internet finance Service. }\end{array}$ & 0.032 & Supported \\
\hline $\begin{array}{c}\text { H2e: Experience has a positive moderator } \\
\text { effect on Objective Usability to Perceived } \\
\text { Ease of Use. }\end{array}$ & 0.01 & $\begin{array}{l}\text { With } \\
\text { moderator } \\
\text { effect }\end{array}$ & $\begin{array}{l}\text { H13: Objective Usability has a } \\
\text { positive influence on Perceived Ease } \\
\text { of Use of internet finance Service. }\end{array}$ & $* * *$ & Supported \\
\hline $\begin{array}{l}\text { H2f: Experience has a positive moderator } \\
\text { effect on Perceived Ease of Use to Perceived } \\
\text { Usefulness of internet finance Service. }\end{array}$ & 0.894 & $\begin{array}{l}\text { Without } \\
\text { moderator } \\
\text { effect }\end{array}$ & $\begin{array}{c}\text { H14: Perceived Ease of Use has a } \\
\text { significant difference on Perceived } \\
\text { Usefulness of internet finance } \\
\text { Service. }\end{array}$ & $* * *$ & Supported \\
\hline $\begin{array}{l}\text { H2g: Experience has a positive moderator } \\
\text { effect on Perceived Ease of Use to } \\
\text { Behavioral Intention of internet finance } \\
\text { Service. }\end{array}$ & 0.397 & $\begin{array}{l}\text { With } \\
\text { moderator } \\
\text { effect }\end{array}$ & $\begin{array}{l}\text { H14-a: Perceived Ease of Use has a } \\
\text { positive influence on Behavioral } \\
\text { Intention of internet finance Service. }\end{array}$ & 0.187 & Not supported \\
\hline $\begin{array}{l}\text { H3: Voluntariness has a positive moderator } \\
\text { effect on Subjective Norm to Behavioral } \\
\text { Intention of internet finance Service. }\end{array}$ & 0.855 & $\begin{array}{l}\text { Without } \\
\text { moderator } \\
\text { effect }\end{array}$ & $\begin{array}{l}\text { H15: Perceived Usefulness has a } \\
\text { positive influence on Behavioral } \\
\text { Intention of internet finance Service. }\end{array}$ & $* * *$ & Supported \\
\hline $\begin{array}{c}\text { H4: Image has a positive influence on } \\
\text { Perceived Usefulness of internet finance } \\
\text { Service. }\end{array}$ & 0.086 & Not supported & $\begin{array}{l}\text { H16: Behavioral Intention has a } \\
\text { positive influence on Use Behavior of } \\
\text { internet finance Service. }\end{array}$ & $* * *$ & Supported \\
\hline
\end{tabular}

H2, H2a-g, H3 are moderator test. 


\subsection{Path Coefficient (Table 7)}

The H8, H12, H13 hypotheses are significant supported but the path coefficient are negative. The H12 Computer Anxiety and Perceived Ease of Use path coefficient are negative. The H8 and H13 are positive. The H15 Perceived Usefulness has a positive influence on the Behavioral Intention of internet finance service and the H16 Behavioral Intention has a positive influence on the Use Behavior of the internet finance service has the highest path coefficient of 0.852 and 0.895 .

\section{Discussion and Conclusions}

This study adopted Venkatesh and Bala (2008) proposed Technology Acceptance Model (TAM3) to understand the key factors of the consumer acceptance of internet finance and its association with satisfaction. The demography result found that participants with a higher education level, more than $80 \%$ have experience of shopping online or shopping through internet or television. Half of the people usually pay by cash or credit card, and are

\section{Table 7. Path coefficient.}

\begin{tabular}{|c|c|c|c|c|c|}
\hline Hypotheses & $\mathrm{N}=307$ & Hypotheses & $\mathrm{N}=307$ & Hypotheses & $\mathrm{N}=307$ \\
\hline $\begin{array}{l}\text { H1: Subjective Norm has a positive } \\
\text { influence on Behavioral Intention of } \\
\text { internet finance Service. }\end{array}$ & -0.028 & $\begin{array}{l}\text { H2f: Experience has a positive } \\
\text { moderator effect on Perceived } \\
\text { Ease of Use to Perceived } \\
\text { Usefulness of internet finance } \\
\text { Service. }\end{array}$ & 0.07 & $\begin{array}{c}\text { H10: Computer Anxiety has a } \\
\text { negative influence on Perceived } \\
\text { Ease of Use of internet finance } \\
\text { Service. }\end{array}$ & -0.110 \\
\hline $\begin{array}{l}\text { H1a: Subjective Norm has a } \\
\text { positive influence on Perceived Use- } \\
\text { fulness of internet finance } \\
\text { Service. }\end{array}$ & 0.046 & $\begin{array}{c}\text { H2g: Experience has a positive } \\
\text { moderator effect on Perceived } \\
\text { Ease of Use to Behavioral } \\
\text { Intention of internet finance Ser- } \\
\text { vice. }\end{array}$ & -0.31 & $\begin{array}{c}\text { H11: Computer Playfulness has a } \\
\text { positive influence on Perceived } \\
\text { Ease of Use of internet finance } \\
\text { Service. }\end{array}$ & -0.129 \\
\hline $\begin{array}{c}\text { H1b: Subjective Norm has a } \\
\text { significant difference on the image } \\
\text { of internet finance Service. }\end{array}$ & 0.808 & $\begin{array}{l}\text { H3: Voluntariness has a positive } \\
\text { moderator effect on Subjective } \\
\text { Norm to Behavioral Intention of } \\
\text { internet finance Service. }\end{array}$ & 0.08 & $\begin{array}{c}\text { H12: Perceived Enjoyment has a } \\
\text { positive influence on Perceived } \\
\text { Ease of Use of internet finance } \\
\text { Service. }\end{array}$ & 0.175 \\
\hline $\begin{array}{l}\text { H2: Experience has a positive } \\
\text { moderator effect on Subjective Norm } \\
\text { to Behavioral Intention of internet } \\
\text { finance Service. }\end{array}$ & -0.14 & $\begin{array}{c}\text { H4: Image has a positive } \\
\text { influence on Perceived Usefulness } \\
\text { of Internet finance Service. }\end{array}$ & 0.068 & $\begin{array}{c}\text { H13: Objective Usability has a } \\
\text { positive influence on Perceived } \\
\text { Ease of Use of internet finance } \\
\text { Service. }\end{array}$ & 0.485 \\
\hline $\begin{array}{l}\text { H2a: Experience has a positive } \\
\text { moderator effect on Image to } \\
\text { Perceived Usefulness of internet } \\
\text { finance Service. }\end{array}$ & -0.05 & $\begin{array}{l}\text { H5: Job Relevance has a positive } \\
\text { influence on Perceived Usefulness } \\
\text { of internet finance Service. }\end{array}$ & 0.144 & $\begin{array}{l}\text { H14: Perceived Ease of Use has a } \\
\text { significant difference on } \\
\text { Perceived Usefulness of internet } \\
\text { finance Service. }\end{array}$ & 0.643 \\
\hline $\begin{array}{l}\text { H2b: Experience has a positive } \\
\text { moderator effect on Computer } \\
\text { Anxiety to Perceived Ease of Use. }\end{array}$ & 0.126 & $\begin{array}{l}\text { H6: Output Quality has a positive } \\
\text { influence on Perceived Usefulness } \\
\text { of internet finance Service. }\end{array}$ & 0.599 & $\begin{array}{l}\text { H14-a: Perceived Ease of Use has } \\
\text { a positive influence on Behavioral } \\
\text { Intention of internet finance } \\
\text { Service. }\end{array}$ & 0.111 \\
\hline $\begin{array}{l}\text { H2c: Experience has a positive } \\
\text { moderator effect on Computer } \\
\text { Playfulness to Perceived Ease of Use. }\end{array}$ & 0.084 & $\begin{array}{c}\text { H7: Result Demonstrability has a } \\
\text { positive influence on Perceived } \\
\text { Usefulness of internet finance } \\
\text { Service. }\end{array}$ & -0.344 & $\begin{array}{l}\text { H15: Perceived Usefulness has a } \\
\text { positive influence on Behavioral } \\
\text { Intention of internet finance } \\
\text { Service. }\end{array}$ & 0.852 \\
\hline $\begin{array}{l}\text { H2d: Experience has a positive } \\
\text { moderator effect on Perceived } \\
\text { Enjoyment to Perceived Ease of Use. }\end{array}$ & -0.56 & $\begin{array}{c}\text { H8: Computer self-efficiency has } \\
\text { a positive influence on Perceived } \\
\text { Ease of Use of internet finance } \\
\text { Service. }\end{array}$ & 0.235 & $\begin{array}{c}\text { H16: Behavioral Intention has a } \\
\text { positive influence on Use } \\
\text { Behavior of internet finance } \\
\text { Service. }\end{array}$ & 0.895 \\
\hline $\begin{array}{l}\text { H2e: Experience has a positive } \\
\text { moderator effect on Objective } \\
\text { Usability to Perceived Ease of Use. }\end{array}$ & 0.262 & $\begin{array}{l}\text { H9: Perceptions of External } \\
\text { Control has a positive influence } \\
\text { on Perceived Ease of Use of } \\
\text { internet finance Service. }\end{array}$ & 0.198 & & \\
\hline
\end{tabular}


surrounded by a good financial environment in a banking facility. Those participants will result in a possibility using an alternative internet finance service. The result also demonstrates that more than $50 \%$ participants are willing to deal with their personal finance by using internet finance.

The result of present Perceived Usefulness is the antecedent of internet finance Behavioral Intention and will result in Use Behavior. This research supports Job Relevance, Output Quality, and Result Demonstrability which means the internet's finance platform's relative job or financial service quality stability has significant positive influence on the Perceived Usefulness of internet finance service. On the other hand, construct of Result Demonstrability has a negative impact on Perceived Usefulness. The result found that the security of the system is highly important. Taiwan's finance customers doubt the circumstances of information security and personal privacy, which has resulted in negative impact on Perceived Usefulness. The result also demonstrated that customers' higher expect for information security had negative influence on Perceived Usefulness. Therefore, internet finance companies should be aware of this problem and improve their information security environment.

The results also found that Perceived Ease of Use has a positive influence on the Perceived Usefulness of the internet finance. The Perceived Ease of Use is the antecedent of Computer self-efficiency, Computer Anxiety, Computer Playfulness, Perceived Enjoyment, and Objective Usability, which means the customer's perception of ability to use the internet, the degree of preference, feel happy and useful experience, those constructs have a positive influence on Perceived Ease of use. Research demonstrated that Computer Playfulness has a negative correlation with Perceived Ease of Use. Research results confirm that Taiwan's consumers prefer high technology products with complex function to fulfill their needs. Therefore, Participants have the opposite view-point on the construct of Perceived Ease of Use.

In the TAM3 model, the result was that both Subjective Norm and Image do not have a significant impact on Perceived Usefulness. Perceptions of External Control have no impact on Perceived Ease of Use. Perceived Ease of Use has no impact on Behavioral Intention of internet finance service. The results demonstrated that Subject Norm and Image have no influence on Perceived Usefulness. The internet finance's Perceptions of External Control have no influence on Perceived of Ease of Use, although it does have an effect on internet finance Ease of Use, but it has no influence on a customer's Use Behavior. From the moderator effect result, Experience has a positive moderator effect on Objective Usability to Perceived Ease of Use. The remainder hypotheses did not support the moderator effect of Experience. The result also demonstrated that Taiwan customers are facing a brand new experience with internet finance service. Moreover, Experience is not the moderator of Perceived of Ease of Use.

In Taiwan, with it mature environment of finance service, customers can easily to locate a bank, a convenience store, a post office and an ATM. In word, the customers could easily switch their intention to other finance service options. In summary of the key factors that influence Taiwan customers to accept internet finance service, conclusions of this study are as follows:

1. From TAM3, this research supports Job Relevance, Output Quality, and Result Demonstrability which have a positive influence on Perceived Usefulness. Computer self-efficacy, Computer Anxiety, Computer Playfulness, Perceived Enjoyment, and Objective Usability have a positive influence on Perceived Ease of Use. Moderator of Experience, has a moderator effect on Objective Usability to Perceived Ease of Use. Perceived Ease of use has a positive influence on Perceived Usefulness and results in a positive influence on Behavioral Intention.

2. The result demonstrated that as Taiwan finance customers have high expectations about information security, the business environment of internet finance security needs improvement.

3. The result confirms Taiwan's consumer preferences for high technology products with complex function to fulfill their needs. Perceived Ease of Use is not one of their options.

4. The result also found that Taiwan finance customers can easily locate banks, convenience stores, post offices and ATMs, and demand a high technology product with complex functions. Therefore, the customer's Behavioral Intention was influenced by Perceived of Usefulness, not Perceived of Ease of Use. This research concludes that when making use of experience of internet finance from other developed countries, Taiwan consumers identify the value of Perceived of Usefulness for switching their Behavioral Intention to an internet finance platform.

The limitations of this study:

1. Research Survey sampling from native Taiwanese population of finance consumers was restricted because of cultural difference, financial maturity and consumer habits. The researcher suggests that future research of 
internet finance development could concentrate on those factors.

2. A consumer's cognitive perception of internet finance may affect the results. The author recommends that future researches focus on a specific internet finance platform or discover the differences between the customer groups.

\section{References}

[1] Hong Kong Edge (2015) Interview with Mr. Joseph King. A Magazine for the Hong Kong Market, Issue 13, December 2015.

[2] Balasubramanian, S., Jaganathan, V. and Natarajan, T. (2014) Information Systems Success in the Context of Internet Banking: Scale Development. JIBC, 19, No. 3

[3] Dhurup, M., Surujlal, J. and Redda, E. (2014) Customer Perceptions of Online Banking Service Quality and Its Relationship with Customer Satisfaction and Loyalty. Mediterranean Journal of Social Sciences, 5, No. 8.

[4] Karimzadeh, M. and Alam, D. (2012) Electronic Banking Challenges in India: An Empirical Investigation. Interdisciplinary Journal of Contemporary Research in Business, 4, No. 2.

[5] Xue, M., Hitt, L.M. and Chen, P.Y. (2011) Determinants and Outcomes of Internet Banking Adoption. Management Science, 57, No. 2. http://dx.doi.org/10.1287/mnsc.1100.1187

[6] Curran, J.M. and Meuter, M.L. (2005) Self-Service Technology Adoption: Comparing Three Technologies. Journal of Services Marketing, 19, 103-113. http://dx.doi.org/10.1108/08876040510591411

[7] Mangin, J.P.L. and Bourgault, N. (2014) The Moderating Role of Risk, Security and Trust Applied to The TAM Model in The Offer of Banking Financial Services in Canada. JIBC, 19, No. 2.

[8] Venkatesh, V., Thong, J.Y.L. and Xu, X. (2012) Consumer Acceptance and Use of Information Technology: Extending the Unified Theory of Acceptance and Use of Technology. MIS Quarterly, 36, 157-178.

[9] Ismail, M.A. and Osman, M.A.Y. (2012) Factors Influencing the Adoption of E-banking in Sudan: Perceptions of Retail Banking Clients. Journal of Internet Banking and Commerce, 17, No. 3.

[10] Fonchamnyo, D.C. (2013) Customers' Perception of E-banking Adoption in Cameroon: An Empirical Assessment of an Extended TAM. International Journal of Economics and Finance, 5, No. 1.

[11] Yousafzai, S.Y. (2012) A Literature Review of Theoretical Models of Internet Banking Adoption at the Individual Level. Journal of Financial Services Marketing, 17, 215-226. http://dx.doi.org/10.1057/fsm.2012.19

[12] Machogu, A.M. and Okiko, L. (2015) E-Banking Complexities and the Perpetual Effect on Customer Satisfaction in Rwandan Commercial Banking Industry: Gender as a Moderating Factor. Journal of Internet Banking and Commerce 20, No. 3.

[13] Lai, P.C. and Ahmad, Z.A. (2015) Consumers' Intention to Use a Single Platform E-Payment System: A Study among Malaysian Internet and Mobile Banking Users. JIBC, 20, No. 1.

[14] Aliyu, A.A., Rosmain1, T. and Takala, J. (2013) Online Banking and Customer Service Delivery in Malaysia: Data Screening and Preliminary Findings. International Conference on Innovation, Management and Technology Research, Malaysia, 22-23 September, 2013.

[15] Namahoot, K.S. and Laohavichien T. (2015) An Analysis of Behavioral Intention to Use Thai Internet Banking with Quality Management and Trust. Journal of Internet Banking and Commerce, 20, No. 3.

[16] Paschaloudis, D. and Tsourela, M. (2014) Using E-S-QUAL to Measure Internet Service Quality of E-Banking Web Sites in Greece. JIBC, 19, No. 1.

[17] Kundu, S. and Datta, S.K. (2014) Customer Loyalty towards Internet Banking: Some Survey Evidence for Banks in India. The IUP Journal of Bank Management, XIII, No. 4.

[18] Safeena, R., Kammani, A. and Date, H. (2013) Assessment of Internet Banking Adoption: An Empirical Analysis. Arabian Journal for Science and Engineering, 39, 837-849.

[19] Davis, F.D. (1989) Perceived Usefulness, Perceived Ease of Use, and User Acceptance of Information Technology, MIS Quarterly, 13, 319-340. http://dx.doi.org/10.2307/249008

[20] Davis, F.D. (1993) User Acceptance of Information Technology: System Characteristics, User Perceptions and Behavioral Impacts. International Journal of Man-Machine Studies, 38, 475-487. http://dx.doi.org/10.1006/imms.1993.1022

[21] Venkatesh, V. and Davis, F.D. (2000) A Theoretical Extension of the Technology Acceptance Model: Four Longitudinal Field Studies. Management Science, 46, 186-204. http://dx.doi.org/10.1287/mnsc.46.2.186.11926

[22] Venkatesh, V. and Bala, H. (2008) Technology Acceptance Model 3 and a Research Agenda on Interventions. Decision Sciences, 39, No. 2. http://dx.doi.org/10.1111/j.1540-5915.2008.00192.x 
Appendix. Questionnaire summery.

\begin{tabular}{|c|c|c|}
\hline Constructs & Items summery & Reference \\
\hline Subjective Norm & $\begin{array}{l}\text { People who are important to me or who influence my behavior think that I should use the } \\
\text { internet finance system. }\end{array}$ & $\begin{array}{l}\text { Venkatesh \& Bata, } \\
\quad 2008\end{array}$ \\
\hline Experience & $\begin{array}{c}\text { With computer system or e-commerce experience will increase my intention to use of } \\
\text { internet finance system. }\end{array}$ & $\begin{array}{l}\text { Venkatesh \& Bata, } \\
\quad 2008\end{array}$ \\
\hline Voluntariness & My use of the internet finance system is voluntary. & $\begin{array}{l}\text { Venkatesh \& Bata, } \\
\quad 2008\end{array}$ \\
\hline Image & $\begin{array}{l}\text { People in my organization who use the internet finance system have a high profile or have } \\
\text { more prestige than those who do not. }\end{array}$ & $\begin{array}{l}\text { Venkatesh \& Bata, } \\
\quad 2008\end{array}$ \\
\hline Job Relevance & In my job, usage of the internet finance system is important or relevant. & $\begin{array}{l}\text { Venkatesh \& Bata, } \\
\quad 2008\end{array}$ \\
\hline Output Quality & $\begin{array}{l}\text { The system is secure and reliable. The quality of the output I get from the system is high } \\
\text { and I rate the results from the internet finance system to be excellent. }\end{array}$ & $\begin{array}{l}\text { Venkatesh \& Bata, } \\
\quad 2008\end{array}$ \\
\hline Result Demonstrability & $\begin{array}{l}\text { I have no difficulty of using the system, the results of using the internet finance system are } \\
\text { apparent to me. }\end{array}$ & $\begin{array}{l}\text { Venkatesh \& Bata, } \\
\quad 2008\end{array}$ \\
\hline Computer self-efficiency & $\begin{array}{l}\text { If I had just the built-in help facility for assistance or someone showed me how to do it } \\
\text { first, I could complete the job using a software package of internet finance. }\end{array}$ & $\begin{array}{l}\text { Venkatesh \& Bata, } \\
\quad 2008\end{array}$ \\
\hline $\begin{array}{l}\text { Perceptions of External } \\
\text { Control }\end{array}$ & $\begin{array}{c}\text { Given the resources, opportunities and knowledge, it would be easy for me to use the } \\
\text { internet finance system. }\end{array}$ & $\begin{array}{l}\text { Venkatesh \& Bata, } \\
\quad 2008\end{array}$ \\
\hline Computer Anxiety & $\begin{array}{l}\text { Using with internet finance computer system makes me nervous, uncomfortable and } \\
\text { uneasy. }\end{array}$ & $\begin{array}{l}\text { Venkatesh \& Bata, } \\
\quad 2008\end{array}$ \\
\hline Computer Playfulness & $\begin{array}{l}\text { How you would characterize yourself when you use computers? Spontaneous, Creative, } \\
\text { and Playful. }\end{array}$ & $\begin{array}{l}\text { Venkatesh \& Bata, } \\
\quad 2008\end{array}$ \\
\hline Perceived Enjoyment & The actual process of using the internet finance system is pleasant, enjoyable and fun. & $\begin{array}{l}\text { Venkatesh \& Bata, } \\
\quad 2008\end{array}$ \\
\hline Objective Usability & $\begin{array}{l}\text { Internet finance system comparison based on the actual level of effort required to complete } \\
\text { specific tasks. }\end{array}$ & $\begin{array}{l}\text { Venkatesh \& Bata, } \\
\quad 2008\end{array}$ \\
\hline Perceived Ease of Use & $\begin{array}{l}\text { My interaction with the internet finance system is clear and understandable, I find the } \\
\text { system to be easy to use. }\end{array}$ & $\begin{array}{l}\text { Venkatesh \& Bata, } \\
\quad 2008\end{array}$ \\
\hline Perceived Usefulness & $\begin{array}{l}\text { Using the internet finance system enhances my effectiveness, increases my productivity } \\
\text { and I find the system to be useful in my job. }\end{array}$ & $\begin{array}{l}\text { Venkatesh \& Bata, } \\
\quad 2008\end{array}$ \\
\hline Behavioral Intention & $\begin{array}{l}\text { I had access to the internet finance system, I intend to use it or plan to use the system in the } \\
\text { future. }\end{array}$ & $\begin{array}{l}\text { Venkatesh \& Bata, } \\
\quad 2008\end{array}$ \\
\hline Use Behavior & Actual use behavior on internet finance system & Davis, 1989 \\
\hline
\end{tabular}

